Journal Club

Editor's Note: These short reviews of recent JNeurosci articles, written exclusively by students or postdoctoral fellows, summarize the important findings of the paper and provide additional insight and commentary. If the authors of the highlighted article have written a response to the Journal Club, the response can be found by viewing the Journal Club at www.jneurosci.org. For more information on the format, review process, and purpose of Journal Club articles, please see http://jneurosci.org/content/ preparing-manuscript\#journalclub.

\title{
Linking the Neuropsychiatric Disease Gene TCF4 to Neuronal Activity-Dependent Regulatory Networks
}

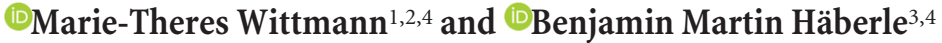 \\ ${ }^{1}$ Institute of Human Genetics, ${ }^{2}$ Research Training Group 2162, Friedrich-Alexander Universität Erlangen-Nürnberg, 91054 Erlangen, Germany, ${ }^{3}$ University \\ Hospital Erlangen IZKF-Doktorandenakademie, Interdisciplinary Center of Neuroscience, ICN School, and ${ }^{4}$ Institute of Biochemistry, Friedrich-Alexander \\ Universität Erlangen-Nürnberg, 91054 Erlangen, Germany \\ Review of Sepp et al.
}

Perturbation of neuronal activity-regulated transcriptional networks has been increasingly linked to the pathophysiology of various neurodevelopmental and psychiatric diseases (Ebert et al., 2013). Transcription factors mediate a significant part of the activity-dependent response of neurons by regulating the expression of genes controlling neural development and plasticity. The transcription factor 4 (TCF4) has recently gathered considerable attention because of its association with both autism spectrum disorder and schizophrenia. Specifically, TCF4 haploinsufficiency causes the autism spectrum disorder-classed Pitt-Hopkins syndrome, while single nucleotide polymorphisms in noncoding and coding regions of TCF4 are associated with an increased risk of schizophrenia (Zweier et al., 2007; Stefansson et al., 2009). Investigating the physiological function and regulation of TCF4 and the pathophysiological consequences of its disease-linked mutations is of major interest, because it may provide deeper insight into patho-

Received Dec. 7, 2017; revised Jan. 31, 2018; accepted Feb. 9, 2018. The authors declare no competing financial interests.

Correspondence should be addressed to Benjamin Martin Häberle, Institute of Biochemistry, Friedrich-Alexander Universität ErlangenNürnberg, Fahrstrasse 17, 91054 Erlangen, Germany. E-mail: benjamin.haeberle@fau.de.

DOI:10.1523/JNEUROSCI.3475-17.2018

Copyright $\odot 2018$ the authors $\quad 0270-6474 / 18 / 382653-03 \$ 15.00 / 0$ physiological pathways shared between these enigmatic diseases.

TCF4 is a ubiquitously expressed class I bHLH transcription factor that binds to Ephrussi-box DNA elements either as a homodimer or as a heterodimer with tissuespecific bHLH factors (Massari and Murre, 2000). TCF4 is broadly expressed in the developing CNS, and its expression is maintained in multiple regions of the adult brain, suggesting functions in neurodevelopment and brain plasticity (Quednow et al., 2014). Only recently have studies begun to address these functions. Developmental knockdown of Tcf4 reduced cortical neuronal spiking by disinhibiting ion channels that hyperpolarize the cell (Rannals et al., 2016), and constitutive Tcf4-haploinsufficiencyled to enhanced long-term potentiation of hippocampal cornu ammonis 1 (CA1) neurons (Kennedy et al., 2016). Overexpression of TCF4 in developing layer $2 / 3$ cortical neurons impaired neuronal migration and disrupted cortical architecture. This defect was attenuated by blocking NMDAR function (Page et al., 2018). These findings not only provided support for the hypothesis that TCF4 functions in both CNS development and postnatal plasticity, but also suggested that TCF4 is regulated by and embedded in neuronal activity-dependent regulatory networks.

A recent study by Sepp et al. (2017) investigated whether TCF4-dependent tran- scription is regulated by neuronal activity (Sepp et al., 2017, their Fig. 1). Sepp et al. (2017) compared the induction of a luciferase reporter gene that was cloned downstream of the TCF4 cis-acting DNA sequence (Ephrussi-box) in untreated and depolarized rat primary neurons transfected with human TCF4 isoforms. Transcriptional activation increased upon neuronal depolarization regardless of the TCF4 isoform subtype expressed (Sepp et al., 2017, their Fig. 1). Synaptic activity induced by blocking GABA type A receptors and $\mathrm{K}^{+}$channels in primary neuron cultures increased TCF4 activity, whereas pharmacological block of L-type voltagegated calcium channels and NMDARs inhibited this effect (Sepp et al., 2017, their Fig. 1). Collectively, these observations identified synaptic activity and $\mathrm{Ca}^{2+}$-dependent signaling pathways as potential upstream regulators of TCF4 function.

The authors subsequently investigated how synaptic activity influences TCF4 activity (Sepp et al., 2017, their Fig. 4). In vitro, inhibiting protein kinase A (PKA) or soluble adenylyl cyclase decreased depolarization-induced TCF4 activity (Sepp et al., 2017, their Fig. 4). Using deletion mutants and Western blot analysis of the TCF4 phosphorylation pattern, the PKA phosphorylatable serine residue (S448) was identified as the potential molecular switch conferring the activity-depend- 
ency of TCF4-mediated gene induction (Sepp et al., 2017, their Figs. 3, 5). To test whether the $S 448$ residue serves an important function in the generation of cortical neurons, the authors exchanged the identified serine residue by alanine to create a nonphosphorylatable TCF4 isoform (S448A mutant) and then in utero electroporated either the TCF4 wild type (WT) or the S448A mutant into the developing cortex. TCF4 WT-overexpressing layer $2 / 3$ prefrontal neurons failed to properly migrate, thereby disrupting the columnar cortex architecture (Sepp et al., 2017, their Fig. 5; Page et al., 2018). Intriguingly, overexpression of the mutated TCF4 isoform did not reproduce this migratory defect (Sepp et al., 2017, their Fig. 5). In vivo, TCF4 function therefore appears to be significantly modulated by its S448 phosphorylation status.

To investigate the possibility that activity-dependent alterations in TCF4 phosphorylation and function constitute a pathophysiological pathway in schizophrenia, Sepp et al. (2017) asked whether sporadic schizophrenia-associated, rare coding single-nucleotide polymorphisms in TCF4 alter the activity-dependent transactivation of TCF4. TCF4 reporter assays in depolarized primary neurons showed that a single-nucleotide polymorphism proximal to the putative phosphorylation site increased neuronal depolarization-induced TCF4 activity (Sepp et al., 2017, their Fig. 7). This suggests that, at least in some cases of TCF4-associated schizophrenia, changes in activity-dependent regulation might contribute to the disease phenotype.

How neuronal activity-induced phosphorylation alters TCF4 function remains to be determined. Phosphorylation can affect multiple levels of protein function such as cellular localization, DNA binding affinity, and protein interaction. Sepp et al., 2017 found that TCF4 is present in the nucleus without stimulation mimicking neuronal activity. Cell depolarization did not alter cellular TCF4 distribution, suggesting that neuronal activity increases TCF4-induced gene expression via mechanisms other than increasing protein translocation to the nucleus (Sepp et al., 2017, their Fig. 2).

Phosphorylation-induced conformational changes might enhance the DNA binding affinity of TCF4. Electromobility shift assays of phosphorylatable, as well as nonphosphorylatable, isoforms showed that phosphorylation is not a conditio sine qua non for DNA binding (Sepp et al., 2017, their Fig. 3). This is in line with the observation that TCF4 is transcriptionally active in nondepolarized cells and raises the possibility that, rather than acting as an on/off switch, phosphorylation serves to fine-tune the transcriptional activity of TCF4 (e.g., through the modulation of its residence time on DNA; Sepp et al., 2012).

Ephrussi-box transcription factors are broadly expressed in multiple cell types in the developing and adult brain (Quednow et al., 2014). It is thought that their transcriptional activity is directed to specific genomic loci by interaction with tissuespecific bHLH transcription factors such as the proneural transcription factors NEUROD1, ATOH1, and ASCL1 (Persson et al., 2000; Suzuki et al., 2001; Flora et al., 2007; Brzózka et al., 2010). Modulation of the affinity of TCF4 for its interaction partners and switches in the choice of interaction partner could determine the differential set of TCF 4 target genes in different cellular contexts. Sepp et al., 2017 observed an increased cooperation of TCF4 and ASCL1 on a putative target gene after depolarization (Sepp et al., 2017, their Fig. 6). This observation raises the possibility that TCF4 functions as a sensor for neuronal activity in transcriptional complexes with proneural bHLH factors, thereby enabling modulation of the transcriptional program of the cell in response to neuronal activity.

Previous work indicated that neuronal subpopulations significantly differ in their requirement for precise TCF4 dosage or activity. For example, overexpression of TCF4 in layer II/III neurons led to a migration defect disturbing the columnar architecture in the medial prefrontal cortex, but not in the somatosensory cortex (Page et al., 2018). The mechanistic principle for this differential vulnerability of developing neuronal subpopulations to TCF4 dosage remains a conundrum. The observation that the migration defect of prefrontal cortex neurons depends on the activity-dependent phosphorylation of TCF4 (Sepp et al., 2017, their Fig. 5; Page et al., 2018) raises the intriguing possibility that activity-dependent phosphorylation and regulation of TCF4 transcriptional function is critical only for a subset of neurons and accounts for the differential vulnerability of neuronal subpopulations to TCF4 dosage.

Another central question in TCF4 function and TCF4-linked pathology is how TCF4 regulates plasticity (Kennedy et al., 2016; Rannals et al., 2016). Loss of TCF4 function increases long-term potentiation in hippocampal CA1, and this is accompanied by dysregulated transcription of plasticity-regulating genes (Kennedy et al., 2016). These transcriptional changes appear to be regulated by altered DNA methylation, indicating that TCF4 governs a broad transcriptional network potentially via interaction with or regulation of the DNA methylation machinery (Kennedy et al. 2016). Interestingly, Sepp et al., 2017 provide evidence that TCF4 regulates the expression of Gadd45y. GADD45 proteins interact with proteins of the demethylation machinery and are thought to target loci for active DNA demethylation (Ma et al., 2009; Sultan et al., 2012). Interestingly, the TCF4 target Gadd45y and its homolog Gadd45b are upregulated upon neuronal activity (Ma et al., 2009; Sultan et al., 2012; Grassi et al., 2017). Activitydependent upregulation of Gadd $45 b$ promotes demethylation in the dentate gyrus subfield and controls long-term potentiation formation in the hippocampal CA1 region (Ma et al., 2009; Sultan et al., 2012). Gadd45y is strongly upregulated upon neuronal depolarization in hippocampal neurons and its level is correlated with altered methylation status of autism-associated genes (Grassi et al., 2017). These findings are intriguingly consistent with the changes in DNA methylation and longterm potentiation formation in Tcf4 haploinsufficient mice (Kennedy et al., 2016). Thus, the present data suggest a model in which activity-dependent regulation of TCF4 generates a transcriptional and epigenetic response that modulates neuronal excitability and potentially neuronal activity patterns. Local network activity patterns are hypothesized to underlie thoughts, perception, and action (Hopfield, 1982; Yuste, 2015), and their disruption is considered a convergence point for the multitude of etiologies in schizophrenia (Hamm et al., 2017). It will, thus, be important to determine whether and how perturbation of TCF4 activity-dependent function affects local patterns of neuronal activity.

The identification of activity-dependent TCF4 function adds a new layer of complexity to its regulation and function, and emphasizes the importance of activitydependent regulatory networks in the pathogenesis of autism spectrum disorder and schizophrenia. Further work to elucidate the precise mechanisms of activitydependent regulation and function of TCF4 might uncover critical pathophysiological pathways shared between these neuropsychiatric entities.

\section{References}

Brzózka MM, Radyushkin K, Wichert SP, Ehrenreich H, Rossner MJ (2010) Cognitive and 
sensorimotor gating impairments in transgenic mice overexpressing the schizophrenia susceptibility gene Tcf4 in the brain. Biol Psychiatry 68:33-40. CrossRef Medline

Ebert DH, Gabel HW, Robinson ND, Kastan NR, Hu LS, Cohen S, Navarro AJ, Lyst MJ, Ekiert R, Bird AP, Greenberg ME (2013) Activitydependent phosphorylation of MeCP2 threonine 308 regulates interaction with NCoR. Nature 499:341-345. CrossRef Medline

Flora A, Garcia JJ, Thaller C, Zoghbi HY (2007) The E-protein Tcf4 interacts with Math1 to regulate differentiation of a specific subset of neuronal progenitors. Proc Natl Acad Sci U S A 104:15382-15387. CrossRef Medline

Grassi D, Franz H, Vezzali R, Bovio P, Heidrich S, Dehghanian F, Lagunas N, Belzung C, Krieglstein K, Vogel T (2017) Neuronal activity, TGFbeta-signaling and unpredictable chronic stress modulate transcription of Gadd45 family members and DNA methylation in the hippocampus. Cereb Cortex 27:4166-4181. CrossRef Medline

Hamm JP, Peterka DS, Gogos JA, Yuste R (2017) Altered Cortical Ensembles in Mouse Models of Schizophrenia. Neuron 94:153-167.e8. CrossRef

Hopfield JJ (1982) Neural networks and physical systems with emergent collective computational abilities. Proc Natl Acad Sci U S A 79: 2554-2558. CrossRef Medline

Kennedy AJ, Rahn EJ, Paulukaitis BS, Savell KE, Kordasiewicz HB, Wang J, Lewis JW, Posey J, Strange SK, Guzman-Karlsson MC, Phillips SE, Decker K, Motley ST, Swayze EE, Ecker DJ, Michael TP, Day JJ, Sweatt JD (2016) Tcf4 regulates synaptic plasticity, DNA methylation, and memory function. Cell Rep 16: 2666-2685. CrossRef Medline

Ma DK, Jang MH, Guo JU, Kitabatake Y, Chang
ML, Pow-Anpongkul N, Flavell RA, Lu B, Ming GL, Song H (2009) Neuronal activityinduced Gadd45b promotes epigenetic DNA demethylation and adult neurogenesis. Science 323:1074-1077. CrossRef Medline

Massari ME, Murre C (2000) Helix-loop-helix proteins: regulators of transcription in eucaryotic organisms. Mol Cell Biol 20:429-440. CrossRef Medline

Page SC, Hamersky GR, Gallo RA, Rannals MD, Calcaterra NE, Campbell MN, Mayfield B, Briley A, Phan BN, Jaffe AE, Maher BJ (2018) The schizophrenia- and autism-associated gene, transcription factor 4 regulates the columnar distribution of layer $2 / 3$ prefrontal pyramidal neurons in an activity-dependent manner. Mol Psychiatry 23:304-315. CrossRef Medline

Persson P, Jögi A, Grynfeld A, Påhlman S, Axelson $\mathrm{H}$ (2000) HASH-1 and E2-2 are expressed in human neuroblastoma cells and form a functional complex. Biochem Biophys Res Commun 274:22-31. CrossRef Medline

Quednow BB, Brzózka MM, Rossner MJ (2014) Transcription factor 4 (TCF4) and schizophrenia: integrating the animal and the human perspective. Cell Mol Life Sci 71:2815-2835. CrossRef Medline

Rannals MD, Page SC, Campbell MN, Gallo RA, Mayfield B, Maher BJ (2016) Neurodevelopmental models of transcription factor 4 deficiency converge on a common ion channel as a potential therapeutic target for Pitt Hopkins syndrome. Rare Dis 4:e1220468. CrossRef Medline

Sepp M, Pruunsild P, Timmusk T (2012) PittHopkins syndrome-associated mutations in TCF4 lead to variable impairment of the transcription factor function ranging from hypomorphic to dominant-negative effects. Hum Mol Genet 21:2873-2888. CrossRef Medline
Sepp M, Vihma H, Nurm K, Urb M, Page SC, Roots K, Hark A, Maher BJ, Pruunsild P, Timmusk T (2017) The intellectual disability and schizophrenia associated transcription factor TCF4 is regulated by neuronal activity and protein kinase A. J Neurosci 37:1051610527. CrossRef Medline

Stefansson H, Ophoff RA, Steinberg S, Andreassen OA, Cichon S, Rujescu D, Werge T, Pietiläinen $\mathrm{OP}$, Mors $\mathrm{O}$, Mortensen $\mathrm{PB}$, Sigurdsson E, Gustafsson O, Nyegaard M, Tuulio-Henriksson A, Ingason A, Hansen T, Suvisaari J, Lonnqvist J, Paunio T, Børglum $\mathrm{AD}$, et al. (2009) Common variants conferring risk of schizophrenia. Nature 460:744747. CrossRef Medline

Sultan FA, Wang J, Tront J, Liebermann DA, Sweatt JD (2012) Genetic deletion of Gadd45b, a regulator of active DNA demethylation, enhances long-term memory and synaptic plasticity. J Neurosci 32:17059-17066. CrossRef Medline

Suzuki H, Fukunishi Y, Kagawa I, Saito R, Oda H, Endo $\mathrm{T}$, Kondo S, Bono $\mathrm{H}$, Okazaki $\mathrm{Y}$, Hayashizaki Y (2001) Protein-protein interaction panel using mouse full-length cDNAs. Genome Res 11:1758-1765. CrossRef Medline

Yuste R (2015) From the neuron doctrine to neural networks. Nat Rev Neurosci 16:487497. CrossRef Medline

Zweier C, Peippo MM, Hoyer J, Sousa S, Bottani A, Clayton-Smith J, Reardon W, Saraiva J, Cabral A, Gohring I, Devriendt K, de Ravel T, Bijlsma EK, Hennekam RC, Orrico A, Cohen M, Dreweke A, Reis A, Nurnberg P, Rauch A (2007) Haploinsufficiency of TCF4 causes syndromal mental retardation with intermittent hyperventilation (Pitt-Hopkins syndrome). Am J Hum Genet 80:994-1001. CrossRef Medline 